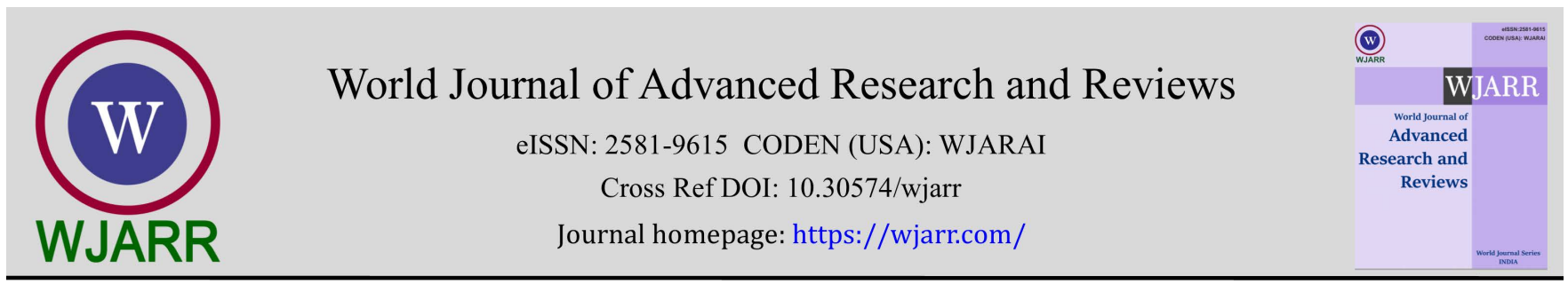

(REVIEW ARTICLE)

\title{
From the concept of economic development to local economic development
}

\author{
Namita Kumari $1{ }^{*}$ and Suman Bhanoo ${ }^{2}$ \\ ${ }^{1}$ SPM College, University of Delhi. \\ ${ }^{2}$ Lady Sri Ram College, University of Delhi.
}

World Journal of Advanced Research and Reviews, 2022, 13(02), 076-081

Publication history: Received on 24 December 2021; revised on 31 January 2022; accepted on 02 February 2022

Article DOI: https://doi.org/10.30574/wjarr.2022.13.2.0108

\begin{abstract}
Growth in Gross domestic product or per capita income is a necessary element of economic development but not sufficient one. This separates economic growth from economic development. These days the Human development index is also taken as the most important measure for economic development. However with the failure of trickle-down theory, economists started looking for other dimensions related to developmental economics. Local economic development shifts the focus both in terms of actors and activities. It demands human, institutional and physical resources to be used at locally to develop any particular region. Although many theories have tried to explain local economic development, there is no comprehensive theory has come up. Blakely in his work has tried to synthesize all the relevant theories. This article also provides two examples related to both these policies to highlight the importance of local development.
\end{abstract}

Keywords: Local development; Development; AMUL; Economic development; Economic growth

\section{Concept of Economic Development}

Economic development is a discipline of economics, concerned with the study of macroeconomic factors that influence long-term economic growth, as well as microeconomic issues affecting individuals and businesses, particularly in emerging nations [1]. On the one hand, the idea of economic growth is mainly concerned about economic output and indicators like Gross National Income (GNP). On the other hand, the idea of economic development necessarily contains these aspects but these are not sufficient to make economic development. Economic development leads to a progressive change in the socio-economic structure of the country. So unlike economic growth, it is also concerned about changes in technological and institutional mechanisms of production as well as distribution.

Some scholars argue that economic development is a concept related to developing countries and economic growth is related to developed countries. But others feel that the difference between them is about nature and cause of change and not about the type of economy. According to Schumpeter, development is a discontinuous, spontaneous change from steady state that lasts forever and replaces the previous equilibrium. Growth, on the other hand, is a long-term change caused by savings and population growth. [2] However, in recent times some economists have tried to put a more broader and inclusive concept of economic development. According to Amartya Sen [3] development is the process of increasing people's real liberties. Individuals are ultimately responsible for making this a reality. Individuals, on the other hand, are hampered by social, political, and economic circumstances. As a result, only a social order that recognises individual freedom as a commitment can attain and preserve the centrality of individual freedom [4].

\footnotetext{
* Corresponding author: Namita Kumari

SPM College, University of Delhi.

Copyright $(2022$ Author(s) retain the copyright of this article. This article is published under the terms of the Creative Commons Attribution Liscense 4.0.
} 


\section{Measurement of Economic Development}

There are four important ways to measure economic development. These are:

- Gross National Product (GNP)- This measures the increase in real national incomes for a long period of time.

- GNP per Capita - This measures the increase in per capita related income over a long period.

- Welfare - This measures the inflow of goods and services to individuals.

- $\quad$ Social Indicators - This takes the basic needs of individuals into consideration.

Hicks and Streeten, take six indicators for basic needs. These are: health, education, food, water supply, sanitation and housing. Economists have attempted to quantify social indicators of basic needs by combining one, two, or more indicators to create composite human development indices. [5] The human development Index is a milestone in this direction. In its annual Human Development Report, since 1990, the United Nations provides an index for selected countries. The HDI is a measure of human progress in its broadest sense. It assesses a country's average achievements across three key criteria of human development.

\section{From Economic Development to Local Economic Development}

With the emergence of new independent states in Asia and Africa, the issue of growth and development became more important for these regions. Economic independence, unlike political independence, cannot be legislated. A deep understanding about the forces of development was required for the establishment of appropriate policies which can further support the overall development. To do this, an economist's creative input was required. [6] This led to the emergence of the concept of economic development in its modern form.

During the 1950s and early 1960s, development policies stressed capital accumulation and industrialization based on import substitution to maximize GNP growth. [7] But in the 1960s and 70s it was realized that the number of people living below the poverty line was increasing. Hence it was found that mere growth in GDP or GNP per capita is not leading to overall development. In a sense the 'trickle down' theory was failing.

They have concentrated almost entirely on addressing perceived "defects" in the poor-inadequate education or skills, a lack of community support, a lack of motivation - while ignoring the very real and powerful barriers to opportunity that the poor face on the "demand" side of the labour market equation. [8] So, we find that at this stage there are many questions were raised against the contemporary concept of economic development. These questions related to various aspects of growth, redistribution, and poverty alleviation. At this point of time some economists re-evaluated the concept and added other important dimensions to it. The World Bank has placed a strong emphasis on redistribution as a result of economic growth. The International Labour Organization focused on the most basic human need. Much of the development literature shifted its focus away from industrial development and toward rural development. [9]

\section{The Substance of Local Economic Development}

Locally oriented economic development represents a significant transformation in the actors and activities related with economic development, not just new terminology. It is basically a strategy for local governments and community-based groups to manage existing resources, build new partnerships with the private sector or each other, create new jobs in a clear economic zone, and promote economic activity. An important element of community-oriented or underlying economic development is to focus on "indigenous development" policies that harness the potential of local people, institutions and physical resources. [10]

In a political sense, at the core of local development lies decentralization and public private partnership. It is widely believed that employment generation is one of the most important characteristics of any development policy. In the case of local development initiatives this can be addressed in a more focused way. As Amartya Sen points out, development is a subset of freedom. And for freedom in a comprehensive sense local development can play a major role. Giving voice to people, can make them decide about their own options and initiatives.

There can be various types of definition of local economic development. Some may focus on actors, mechanisms of local economic development or on expected outcomes. Addressing how the activities affect the individual or the community can also be emphasized.

We can see some theories which partially explain the local economic development. 


\subsection{Economic Base Theory}

Adherents of the economic foundation/base theory think that the drivers of economic growth are inextricably linked to demand for high-quality services and products from outside the community's economic boundaries. To put it another way, expanding businesses that employ local resources like labour and materials for final export elsewhere will generate both cash and jobs in the area. [11] So, in crux, individuals in a local area will get more work and the community will economically grow. So, any strategy under this theory will emphasize infrastructure facilities plus belief in export based firms and reduction in export barriers. The weakness of this model comes from its overdependence on external demand. Any fluctuation in external demand can send the economy laid wire.

\subsection{The Role of Neoclassical Economic Theory}

In terms of regional and local development, neoclassical theory proposes two fundamental concepts: equilibrium and mobility. These ideas state that if capital may move freely, all economic systems will attain a natural equilibrium. That is, capital will flow from high-wage/cost areas to low-wage/cost sectors, which provide a larger return on investment. In terms of local development, this means that ghettos should attract capital because property and labour prices do not always fulfil market demand. If the model were to work perfectly, all segments of the economy would progressively achieve equal status. [12] These theorists are opposed to government intervention and protective barriers. Here the community needs to be intelligent enough to mobilize its resources to attract the capital.

\subsection{Location Theory}

Location is one of the important points to be kept in mind for any industrial development. Location, not only defines our reach to market but also "labour cost, cost of energy, availability of suppliers communications, education and training facilities". [13] But due to modern technologies as the "death of distance" is stated the significance of location is diminishing.

\subsection{Central Place Theory}

The main premise of central place theory is that places are arranged in a hierarchy. Each metropolitan centre is surrounded by a network of smaller towns that provide both resources (industries and raw materials) and services that require a central clearing house to enter the global market. [14] The central place theory puts emphasis on the importance of functional role. Either an urban area or rural area it is stated that when the central place is developed it will lead to overall development of the entire region.

\subsection{Cumulative Causation Theories}

With the effect of market places, some prosperous areas get more capital inflow and labour inflow. Even the deprived rations send their resources to these areas. The creation of new institutional arrangements to rebuild underserved counties is one solution. Community development corporations and rural development centres are two examples. These groups work to re-establish the market by acting as capital retainers or attractors in places where market forces are particularly weak. [15] The problem with this theory is the lack of data, so it is difficult to establish a relationship. Therefore it is only appropriate for a small area.

\subsection{Attraction models}

This model is based on public private partnership. It envisages improvement in market position with the help of industrialists. And to attract them incentives and subsidies should be given. Communities are made up of products. As a result, they must be "packed" and shown properly. Magazine and newspaper advertisements promoting the merits of certain regions over others provide objective proof of this community packaging. This style of economic development is viewed with considerable scepticism. Nonetheless, there is a lot of evidence that community marketing works, and not using it could be a political liability. [16]

\section{Toward a Synthetic Theory of Local Economic Development}

As we have seen, existing theories are unable to explain the phenomenon of local economic development. So, Edward J. Blakely [17] develops a synthetic theory. Here he takes the components of employment, development base, location assets and knowledge resources. He adds some new concepts related to these components with the old. We are here giving the table from Blakely's book [18] 
Table 1 Local Economic Development Components

\begin{tabular}{|l|l|l|}
\hline Component & old concept & New Concept \\
\hline Employment & More firms=more jobs & Firms that build quality jobs that fit the local population \\
\hline $\begin{array}{l}\text { Development } \\
\text { base }\end{array}$ & Building economic sector & Building new economic institutions \\
\hline $\begin{array}{l}\text { Location assets } \\
\text { Comparative advantage based on } \\
\text { Knowledge } \\
\text { resource }\end{array}$ & Available work force & Knowledge as economic generator \\
\hline
\end{tabular}

\section{Strategies}

Most of the time, employment generation and economic development comes as the immediate goal for community development. Here two questions are important for formulation of any strategy in regard to the problem. One is related to the institutional structure to be followed for employment generation and the second is related to the business investment decision. In both cases employment generation and retention should be taken as the primary goal regardless of the fact, whether it comes from big firms or small firms. Blair John P [19] talks about nine strategies-

- Industrial recruitment/promotion-advertise, to attract new establishments of national interest to an area, provide information, create infrastructure and sites, and offer financial and tax benefits.

- Expansion of existing industries-provide infrastructure, financing, skills training and marketing assistance to support the expansion of larger manufacturers already in an area.

- Worker/community ownership- assist in the formation of new ownership groups, the negotiation of purchase terms, and the provision of financing and other assistance in the transfer of ownership to local inhabitants.

- New enterprise development- assist in the identification of viable ventures, the people who will launch them, and the initial source of funding.

- Small business development- provide business counselling, planning, and finance to help local retailers, service providers, and small manufacturers expand.

- Transition to new ownership-a long-term strategy for locating viable privately held businesses with heirs, matching them with potential new owners, and securing the acquisition financing required to keep the businesses running as going concerns while also providing appropriate compensation to the original owners.

- $\quad$ Brokerage/financing services- by discovering and matching owners looking to sell businesses, we can help with sales and acquisitions. In order to sustain employment levels in these enterprises, potential buyers must find financing from local investors and financial intermediaries.

- Technical assistance- to stop local concerns from contracting, identify and solve specific technical, production, or marketing issues; and

- Management assistance- provide general guidance and assistance to help steady local businesses thrive.

\section{Different Policies Derived from the Two Concepts}

Here for our study and analysis we take two examples respectively related to economic development and local economic development. The first is a five year plan prepared by the central government in India and the second is the milk cooperatives in Gujarat region.

\subsection{Five Year Plans}

India followed a path of centralized developed planning since 1951. Here the government is the main actor devising out strategies for the whole country taken as a unit. Then it mobilizes the domestic resources to meet certain fixed requirements. The primary focus under these are heavy industries and so, the location is decided by the central authority according to different priorities. Sometimes it leads to disparity in development between different areas. The 
planning commission of India was dissolved in 2014. The primary purpose of the planning commission was to prepare a national plan for the utilization of resources and propose the allocation of resources on the priority basis.

Various plan documents in India spelled forth the long-term aims of economic planning. "From the sixth to the seventh five-year plans, the key goals were: a)economic development b)self-sufficiency c)reduction of income disparities d)Poverty eradication and modernization". [20] However it can be deciphered from the experience of last five decades that economic growth was always the prime objective of the planning process. However faced with the problem of acute poverty and hyper unemployment, the planning commission devised some direct strategies to counter the problems. We can identify three primary tactics in the Indian planning process: a) laying a solid foundation for long-term growth; b) giving industrialization a high priority; and c) emphasising the development of capital goods sectors above consumer goods businesses.

\subsection{Gujrat milk cooperatives}

Now we will see a case of local development. Here we are giving the example of dairy cooperatives in Gujarat. Cooperative, in simple terms, can be understood as activities of people for mutual help and benefit as well as for collective progress and common interests. At present Gujarat is having one of the world's largest and diverse cooperative societies covering almost all areas like agriculture- crediting, marketing, supplies, processing, industrial cooperatives, housing cooperatives, functional cooperatives in the field like dairy, fisheries, fruits and vegetables etc. The development of cooperative societies was slow until a significant turn took place in the cooperative movements when world's largest dairy development program 'Operation Flood' was introduced in India by National Dairy Development Board (NDDB) in 1970. NDDB which was established in 1965 is a federation of many states and the largest milk producer in the world. This operation is also known as the 'white revolution' of India. With the initiation of this project, dairy cooperatives have emerged as one of the most important and largely profitable cooperative societies in India. Gujarat is the first state where the first dairy cooperative was established. And since then to the till date this state is on the top. However some other states like Rajasthan, Maharashtra, Punjab and Haryana, Tamilnadu have also done a significant improvement in cooperative societies especially in the dairy sector. In 1946, the first cooperative society was established in Kaira district in Gujarat named 'Kaira District cooperative Milk Producers Union limited' (KDCM) to sell milk directly without involving middle men. In 1954 KDCM started converting surplus milk into powder and butter and in 1958 a cheese manufacturing plant was started. In 1946 ,AMUL (Anand Milk-producers Union Limited) was formed under the dairy cooperative movement in India.

Gujarat comes first among all states where many dairy cooperatives are run solely by women. Banaskantha district is the first place in India where the concept of all women dairy cooperative was started. Since then many cooperatives are working. For example, in Surendranagar district, in Santhalpur and Radhanpur talukas SEWA has restarted the closed dairies. Some other places like Halvad in Mayurnagar, New Ganshyamgardh, Juna Amrapur, Mayapur, Kidi, Miyani and many dairy cooperatives were established. Deepak Trust of Charity (DTC) in Vadodara district is promoting women's dairy in Vadodara. Gujarat based NDDB and some governmental organizations are running some educational programs where a large number of women participated. By these schemes women are getting information about fodder, mineral mixtures and cattle health training. They are getting loans for cattle and other livelihood activities and cattle insurance. Dairy cooperatives have transformed the life of almost all women associated with them.

In recent years, the milk cooperative movement has experienced a substantial increase in milk production. The main reasons are efficient milk collection and higher profit for producers. Dairy Information Services Kiosk(DISK) is helping cooperatives and farmers to manage a database of all milch cattle and many other information. The functioning of dairy cooperatives is mainly divided at two levels- at village and at district level. The production, collection, processing and marketing of milk and milk products are going through a long system. Every village has village milk cooperatives under the supervision of the milk supply officer of Cooperative Dairy Union (District level cooperative owning the processing of the plant).

NDDB and organizations like Grameen Bank (village Bank), is investing in villages. From where the farmers can get loans for buying cattle, fodders etc. NDDB is financing 30\%-70\% loan under 'operation flood program. We can see here that in different regions of this state with the cooperative movement all the necessary elements of development and growth are being achieved.

\section{Conclusion}

The idea of economic development was a dominant tool used by economists around the world. However, there had been challenges to this traditional idea. There were arguments around the inclusion of social indicators and other democratic 
ideals in the developmental narrative. The concept of Human Development Indicator was an important milestone in this direction. The concept of local development can be understood within this framework. The idea of local development is essentially a plan for local governments and community-based organisations to manage current resources, form new partnerships with the private sector or with one another, create new jobs in a defined economic zone, and encourage economic activity. There are many theories about local economic development. The Synthetic Theory of Local Economic Development proposed by Edward J. Blakely remains a dominant theory. The case of Gujarat milk cooperatives can be given as an example to local economic development. In contemporary times, it is highly imperative for a diverse country like India, to fully move forward from the idea of centralised development planning to local development models. The successes of local development initiatives approve of the fact that greater and deeper engagement of people and communities is the way forward for the development of the nation and empowerment of people.

\section{Compliance with ethical standards}

\section{Acknowledgments}

The authors have not received any grants for this article. Therefore this study was not supported by any grant.

\section{Disclosure of conflict of interest}

For both the authors there is no conflict of interest.

\section{References}

[1] Bhagwati, Jagdish. Development economics: What have we learned?" Asian Development Review. $1984 ; 2$ (1): 67.

[2] Schumpeter JA. The Theory of economic Development, Transaction Publishers. 1934.

[3] Sen Amartya. Development which way now?" The Economic Journal. 1983; 93: 745-762.

[4] ML Jhingan. The Economics of Development and Planning, Vrinda Publications, New Delhi. 1997.

[5] Hicks, Norman \& Streenten Paul. World Development. Pergamon Press. 1979; 7: 567-580.

[6] Schumpeter JA. The Theory of economic Development, Transaction Publishers. 1934.

[7] Quoted in, Edward Blakely. "Planning Local Economic Development”,London: SAGE. 1989.

[8] Gerald M Meier, James E Raud. Leading issues in Economic Development Oxford University Press.2005; 14.

[9] Edward Blakely. "Planning Local Economic Development”,London:SAGE. 1981; 58.

[10] Edward Blakely. "Planning Local Economic Development”,London:SAGE. 1981; 60.

[11] Gerald M Meier, James E Raud. Leading issues in Economic Development Oxford University Press. $2005 ; 74$.

[12] Edward Blakely. “Planning Local Economic Development”,London:SAGE. 1981; 63.

[13] Edward Blakely. "Planning Local Economic Development”,London:SAGE. 1981; 64.

[14] Sen Amartya. Development which way now?” The Economic Journal. 1983; 93: 745-762.

[15] Edward Blakely. "Planning Local Economic Development”,London:SAGE. 1981; 65.

[16] Edward Blakely. “Planning Local Economic Development”,London:SAGE. 1981; 72.

[17] Blair JP. Local economic development" CA:Thousand oaks. 1995; 459.

[18] Mishra and Puri. Indian Economy, New Delhi: Himalaya publishing house. 2003; 872.

[19] Schumpeter JA. The Theory of economic Development, Transaction Publishers. 1934.

[20] Sen Amartya. Development which way now?" The Economic Journal. 1983; 93: 745-762. 